Research Paper

\title{
Efficient production of lignocellulolytic enzymes xylanase, $\beta$-xylosidase, ferulic acid esterase and $\beta$-glucosidase by the mutant strain Aspergillus awamori 2B.361 U2/1
}

\author{
Leda Maria Fortes Gottschalk ${ }^{1}$, Raquel de Sousa Paredes ${ }^{2}$, \\ Ricardo Sposina Sobral Teixeira ${ }^{2}$, Ayla Sant'Ana da Silva ${ }^{2}$, Elba Pinto da Silva Bon ${ }^{2}$ \\ ${ }^{1}$ Bioprocess Laboratory, Embrapa Food Technology, Rio de Janeiro, RJ, Brazil. \\ ${ }^{2}$ Chemistry Institute, Federal University of Rio de Janeiro, Rio de Janeiro, RJ, Brazil.
}

Submitted: October 25, 2011; Approved: July 23, 2012.

\begin{abstract}
The production of xylanase, $\beta$-xylosidase, ferulic acid esterase and $\beta$-glucosidase by Aspergillus awamori 2B.361 U2/1, a hyper producer of glucoamylase and pectinase, was evaluated using selected conditions regarding nitrogen nutrition. Submerged cultivations were carried out at $30^{\circ} \mathrm{C}$ and $200 \mathrm{rpm}$ in growth media containing $30 \mathrm{~g}$ wheat bran/L as main carbon source and either yeast extract, ammonium sulfate, sodium nitrate or urea, as nitrogen sources; in all cases it was used a fixed molar carbon to molar nitrogen concentration of 10.3. The use of poor nitrogen sources favored the accumulation of xylanase, $\beta$-xylosidase and ferulic acid esterase to a peak concentrations of 44,880 ; 640 and $118 \mathrm{U} / \mathrm{L}$, respectively, for sodium nitrate and of 34,580, 685 and $170 \mathrm{U} / \mathrm{L}$, respectively, for urea. However, the highest $\beta$-glucosidase accumulation of $10,470 \mathrm{U} / \mathrm{L}$ was observed when the rich organic nitrogen source yeast extract was used. The maxima accumulation of filter paper activity, xylanase, $\beta$-xylosidase, ferulic acid esterase and $\beta$-glucosidase by $A$. awamori $2 \mathrm{~B} .361 \mathrm{U} 2 / 1$ was compared to that produced by Trichoderma reesei Rut-C30. The level of $\beta$-glucosidase was over 17 -fold higher for the Aspergillus strain, whereas the levels of xylanase and $\beta$-xylosidase were over 2 -fold higher. This strain also produced ferulic acid esterase $(170 \mathrm{U} / \mathrm{L})$, which was not detected in the T. reesei culture.
\end{abstract}

Key words: Aspergillus awamori 2B.361 U2/1, cellulases, hemicellulases, $\beta$-glucosidase, nitrogen nutrition.

\section{Introduction}

The demand to establish renewable feedstock for the production of chemicals and fuels is pressing on the development of the necessary technologies to process biomass both efficiently and economically. The potential use of these residues worldwide is indeed significant; considering biomass availability in Brazil the agroindustry of corn, sugarcane, rice, cassava, wheat, citrus, coconut and grass collectively generate 597 million tons of residues per year (Ferreira-Leitão et al., 2010). For biomass processing, efforts have been made towards the production of efficient and low cost enzyme blends to hydrolyse both the cellulose and the hemicellulose part of the biomass. Efficient cellu- lose hydrolysis requires the cooperative action of endoglucanases (EC 3.2.1.4) and exoglucanases (EC 3.2.1.91), which release cellooligosaccharides and cellobiose, respectively. The enzyme $\beta$-glucosidase (EC 3.2.1.21) cleaves the disaccharide cellobiose into two molecules of glucose - the end product of cellulose hydrolysis (Zhang et al., 2009). The enzymes used for the cellulose degradation have been traditionally produced mostly by fungi belonging to the genus Trichoderma (Gosh and Gosh, 1992) nevertheless its low $\beta$-glucosidase titre (Stockton et al., 1991). As such, $\beta$-glucosidase supplementation is necessary to hydrolyze cellobiose, which is also a strong inhibitor of endo- and exo-glucanase (Howell and Stuck, 1975). To overcome the

Send correspondence to: L.M.F. Gottschalk. Embrapa Food Technology, Bioprocess Laboratory, Av. das Américas 29501, CEP 23020-470, Rio de Janeiro, RJ, Brazil. E-mail: leda@ctaa.embrapa.br. 
Trichoderma enzyme pool deficiency, studies have been carried out on its supplementation with Aspergillus enzymes (Duff et al., 1987; Duenas et al., 1995; Gutierrez-Correa and Tengerdy, 1997; Wen and Chen, 2005; Bon et al., 2009; Gottschalk et al., 2010).

Hemicellulose, which is, after cellulose the second most abundant polysaccharide available in nature (Bastawde, 1992), is processed by the depolymerizing xylanase (EC 3.2.1.8), $\beta$-xylosidase (EC 3.2.1.37) and debranching enzymes such as acetyl esterases (EC 3.1.1.6), $\alpha$-arabinofuranosidases (EC 3.2.1.55), ferulic acid esterases (EC 3.2.1.73) $p$-coumaroyl esterases (EC 3.2.1.73) and $\alpha$-glucuronidase (EC 3.2.1.139). The importance of developing balanced xylanase enzyme pools, containing endo-acting, exo-acting and debranching activities, is crucial to hydrolyse the heterogeneous hemicelluloses structure, allowing the use of the rich C5 sugars syrups stream as feedstock in industrial yeast or bacterial fermentations, for the production of a range of fuels and chemicals such as ethanol, xylitol, 2,3-butanediol, acetone, isopropanol, butanol and hydrogen. Other products include carbon dioxide and organic acids, such as butyric acid, acetic acid, formic acid, succinic acid and lactic acid (Rosenberg, 1980), which presents a higher commercial value in comparison to the ethanol fuel. Aspergillus spp have been widely used as sources of industrial enzymes such as $\beta$-xylosidases (Kurakake et al., 2005), $\beta$-D-manosidases; $\beta$-D-mananases (Kurakake and Tomaki, 2001), $\alpha$-galactosidases (Neustroev et al., 1991), acetyl esterases (Koseki et al., 1997), ferulic acid esterases (Koseki et al., 2006), $\beta$-glucosidases (Anindyawati et al., 1998) and proteinases (Ahmed et al., 2011). The industrial strain Aspergillus awamori 2B.361 U2/1 stands out for its ability to secrete high levels of glucoamylase (Bon and Webb, 1989, 1993; Pavezzi et al., 2008), xylanases and polygalacturonases (Lemos et al., 2000; Botella et al., 2007; Umsza-Guez et al., 2011).

This work aimed to further the knowledge on the ability of the industrial strain Aspergillus awamori 2B.361 $\mathrm{U} 2 / 1$ to efficiently secrete an enzyme pool containing xylanase, $\beta$-xylosidase, ferulic acid esterase and $\beta$-glucosidase, which act on biomass. The fungus physiological response was studied concerning the accumulation of these enzymes, under comparative and selected cultivation conditions regarding the nitrogen nutrition, using amino nitrogen, $\mathrm{NH}_{4}+$, $\mathrm{NO}_{3}$ - or urea. For comparison, the enzymes activity profile of Aspergillus awamori 2B.361 U2/1 was compared to that produced by Trichoderma reesei Rut-C30.

\section{Materials and Methods}

\section{Microorganisms, maintenance and propagation}

Trichoderma reesei Rut-C30 (ATCC 56765) and Aspergillus awamori 2B.361 U2/1, a sequential mutant of A. awamori 3112 (Bon and Webb, 1933; Bon et al., 2007; Gottschalk et al., 2010) were cultured in Petri dishes containing PDA (Potato Dextrose Agar) for seven days at $30{ }^{\circ} \mathrm{C}$. Spore suspensions were obtained by addition of $\mathrm{NaCl} 0.9 \%(\mathrm{w} / \mathrm{v})$ in sporulating Petri plates and subsequently lightly scraping the cultures. The suspensions were centrifuged for 15 min in a Beckman-Coulter Allegra 6R centrifuge and the spores were preserved in glycerol $20 \%$ $(\mathrm{v} / \mathrm{v})$ at $-18^{\circ} \mathrm{C}$.

\section{Enzymes production}

The effect of the nitrogen sources on the production of xylanase, $\beta$-xylosidase, ferulic acid esterase and $\beta$-glucosidase by $A$. awamori $2 \mathrm{~B} .361 \mathrm{U} 2 / 1$ was evaluated in a buffered growth media containing $30 \mathrm{~g}$ wheat bran/L (WB) as carbon source, and either yeast extract (YE), $\left(\mathrm{NH}_{4}\right)_{2} \mathrm{SO}_{4}$, $\mathrm{NaNO}_{3}$ or urea as nitrogen sources, presenting in all cases a fixed millimolar carbon / millimolar nitrogen ratio $(\mathrm{C} / \mathrm{N})$ of 10, plus salts (g/L): $3.0 \quad \mathrm{KH}_{2} \mathrm{PO}_{4}, \quad 6.0 \quad \mathrm{~K}_{2} \mathrm{HPO}_{4}$, $0.2 \mathrm{MgSO}_{4} .7 \mathrm{H}_{2} \mathrm{O}, 0.05 \mathrm{CaCl}_{2} .2 \mathrm{H}_{2} \mathrm{O}$ (Table 1). For comparison Trichoderma reesei Rut-C30 was cultivated in a liquid medium containing $(\mathrm{g} / \mathrm{L})$ : 30 lactose, 6.0 yeast extract, 0.3 urea, $0.6 \%(\mathrm{v} / \mathrm{v})$ corn steep liquor, plus salts $(\mathrm{g} / \mathrm{L})$ : $1.4 \quad\left(\mathrm{NH}_{4}\right)_{2} \mathrm{SO}_{4}, \quad 2.0 \quad \mathrm{KH}_{2} \mathrm{PO}_{4}, \quad 0.3 \quad \mathrm{CaCl}_{2}$ and $0.3 \mathrm{MgSO}_{4} .7 \mathrm{H}_{2} \mathrm{O}$, and trace elements $(\mathrm{mg} / \mathrm{L})$ : $5.0 \mathrm{FeSO}_{4} .7 \mathrm{H}_{2} \mathrm{O}, 20 \mathrm{CoCl}_{2}, 1.6 \mathrm{MnSO}_{4}$ and $1.4 \mathrm{ZnSO}_{4}$ (Mandels and Weber, 1969). Enzymes production by both fungi was carried out in $1000 \mathrm{~mL}$ Erlenmeyer flasks con-

Table 1 - Percentage of carbon and nitrogen concentration in mmol/L of carbon and nitrogen in different nitrogen sources and $\mathrm{C} / \mathrm{N}$ ratio of each medium.

\begin{tabular}{llcccccc}
\hline Medium & Nitrogen and carbon sources & Concentration $(\mathrm{g} / \mathrm{L})$ & $\% \mathrm{C}$ & $\% \mathrm{~N}$ & {$[\mathrm{C}](\mathrm{mmol} / \mathrm{L})$} & {$[\mathrm{N}](\mathrm{mmol} / \mathrm{L})$} & $\mathrm{C} / \mathrm{N} \mathrm{ratio}$ \\
\hline $\mathrm{NaNO}_{3}$ & sodium nitrate & 3.5 & 0.0 & 16.48 & 0.0 & 41.18 & 10.3 \\
& wheat bran & 30 & 57.31 & 4.6 & 1431.44 & 98.52 & \\
\hline \multirow{2}{*}{$\mathrm{YE}$} & yeast extract & 15 & 45.0 & 8.9 & 561.98 & 95.31 & 10.3 \\
& wheat bran & 30 & 57.31 & 4.6 & 1431.44 & 98.52 & 40.83 \\
\hline$\left(\mathrm{NH}_{4}\right)_{2} \mathrm{SO}_{4}$ & ammonium sulphate & 2.7 & 0.0 & 21.18 & 0.0 & 10.3 \\
& wheat bran & 30 & 57.31 & 4.6 & 1431.44 & 98.52 & \\
\hline \multirow{2}{*}{ Urea } & urea & 1.29 & 20.0 & 46.65 & 21.48 & 42.96 & 10.3 \\
& wheat bran & 30 & 57.31 & 4.6 & 1431.44 & 98.52 & \\
\hline
\end{tabular}


taining $300 \mathrm{~mL}$ of growth medium. After sterilization, the culture media were inoculated with a $1 \%(\mathrm{v} / \mathrm{v})$ of spore suspension such that it was obtained a final concentration of $10^{6}-10^{7}$ spores $/ \mathrm{mL}$ growth medium. Triplicate cultures were incubated for seven days in a rotary shaker (New Brunswick model INNOVA 4340) at $30{ }^{\circ} \mathrm{C}, 200 \mathrm{rpm}$. The wheat bran used in this work presented a composition of $70 \%$ of carbohydrates and $20 \%$ of proteins. To calculate the carbon and nitrogen millimolar concentration in each media, the studies of Jones and Gersdorff (1925) and Nandini and Salimath (2001) were considered. According to Jones and Gersdorff (1925), wheat bran presents $1.6 \%$ of free amino nitrogen and its proteins contain $53 \%$ of carbon and $15 \%$ of nitrogen. Thus, considering only the protein fraction, the wheat bran used in this study presented $10.6 \%$ of carbon and $4.6 \%$ of nitrogen. According to Nandini and Salimath (2001) the carbohydrate fraction of wheat bran is composed of $37 \%$ of arabinose, $27 \%$ of xylose and $26 \%$ of glucose. Based on these data, the amount of carbon on each sugar was calculated, resulting in a total carbon of $46.71 \%$, considering only the carbohydrate fraction.

\section{Enzymes activity assays}

The culture supernatants were used for the determination of FPase, CMCase, xylanase, $\beta$-glucosidase, $\beta$-xylosidase and ferulic acid esterase activities. All measurements were performed in duplicates. Filter paper activity (FPA), carboxymethyl cellulase activity (CMCase) and $\beta$-glucosidase (BGU) were determined according to standard IUPAC procedures and expressed as international unit (U) (Ghose, 1987). One unit of FPase or CMCase activity corresponded to the formation of $1 \mu \mathrm{mol}$ of reducing sugar (glucose equivalent) per min using as substrates a $6.0 \times 1.0 \mathrm{~cm}$ filter paper Whatman No.1 strip or 4\% carboxymethylcellulose, respectively. Xylanase activity was determined by mixing $50 \mu \mathrm{L}$ of enzyme solution with $100 \mu \mathrm{L}$ of soluble fraction of oat spelt xylan $(1 \%, \mathrm{w} / \mathrm{v})$ in $100 \mathrm{mM}$ sodium acetate buffer, pH 5.0 at $50{ }^{\circ} \mathrm{C}$ for $30 \mathrm{~min}$ (Teixeira et al., 2010). One unit of xylanase activity was defined by the formation of $1 \mu \mathrm{mol}$ of reducing sugar (xylose equivalent) per minute. Reducing sugars were estimated by 3,5-dinitrosalicylic acid (DNS) method prepared without phenol and metabisulfite (Teixeira et al., 2012). Glucose or xylose were used as standard. One unit of $\beta$-glucosidase activity corresponded the formation of $1 \mu \mathrm{mol}$ of glucose per min using cellobiose as substrate. Glucose concentrations were measured using a Biochemistry Analyzer YSI 2700. Ferulic acid esterase (FAE) activity was assayed by measuring the release of ferulic acid in a reaction mixture containing $10 \mu \mathrm{L}$ of enzyme solution, $20 \mu \mathrm{L}$ of $1 \%$ of ethyl ferulate in dimethylsulfoxide (DMSO), $100 \mu \mathrm{L}$ of $1 \mathrm{M}$ acetate buffer (pH 5.0), plus $870 \mu \mathrm{L}$ of water, at $50{ }^{\circ} \mathrm{C}$ for $20 \mathrm{~min}$. Reaction was terminated by boiling the reaction mixture for $5 \mathrm{~min}$ and the ferulic acid quantified by HLPC. One unit of FAE corresponded to the formation of $1 \mu \mathrm{mol}$ of ferulic acid per minute. $\beta$-xylosidase activity was determined in a reaction mixture containing $50 \mu \mathrm{L}$ of an appropriately diluted enzyme solution, $100 \mu \mathrm{L}$ of $10 \mathrm{mM}$ p-nitrophenyl- $\beta$-Dxylopyranoside, $200 \mu \mathrm{L}$ of $0.5 \mathrm{M}$ sodium acetate buffer $\mathrm{pH}$ 5.0 plus $650 \mu \mathrm{L}$ Milli-Q water, at $50{ }^{\circ} \mathrm{C}$ for $10 \mathrm{~min}$. Reaction was terminated by adding $500 \mu \mathrm{L}$ of $1 \mathrm{M} \mathrm{Na}_{2} \mathrm{CO}_{3}$. The concentration of p-nitrophenol, which is the reaction product, was measured at $400 \mathrm{~nm}$. One unit of $\beta$-xylosidase was defined as the amount of enzyme that released $1 \mu \mathrm{mol}$ of $p$-nitrophenol at $50^{\circ} \mathrm{C}$ in $1 \mathrm{~min}$.

\section{Results}

Effect of $\mathrm{YE},\left(\mathrm{NH}_{4}\right)_{2} \mathrm{SO}_{4}, \mathrm{NaNO}_{3}$ or urea on the production of xylanase, $\beta$-xylosidase, ferulic acid esterase and $\beta$-glucosidase by $A$. awamori

The maximal xylanase, ferulic acid esterase and $\beta$-xylosidase produced by $A$. awamori, as well as the cultivation time to reach the corresponding peak activities using YE, $\left(\mathrm{NH}_{4}\right)_{2} \mathrm{SO}_{4}, \mathrm{NaNO}_{3}$ or urea as nitrogen sources, are presented in Figure 1a, 1b and 1c. Ammonium, nitrate or urea resulted in high levels of xylanase (U/L) $(28,300 \pm$ $3,950,44,880 \pm 1,620$ and 34,580 $\pm 1,880), \beta$-xylosidase $(\mathrm{U} / \mathrm{L})(390 \pm 120,640 \pm 70$ and $685 \pm 110)$ and ferulic acid esterase $(\mathrm{U} / \mathrm{L})(183 \pm 19,118 \pm 3$ and $170 \pm 32)$, respectively. Media containing inorganic nitrogen or urea favored these enzymes accumulation in comparison to that containing the more expensive YE $(12,900 \pm 330 \mathrm{U} / \mathrm{L}$ for xylanase; $210 \pm 20 \mathrm{U} / \mathrm{L}$ for $\beta$-xylosidase and $63 \pm 2 \mathrm{U} / \mathrm{L}$ for ferulic acid esterase). Nitrate favored xylanase $(44,880 \pm$ $1,620 \mathrm{U} / \mathrm{L})$, urea favored $\beta$-xylosidase $(685 \pm 110 \mathrm{U} / \mathrm{L})$ and ammonium favored ferulic acid esterase (183 $\pm 19 \mathrm{U} / \mathrm{L})$ accumulation, whose levels were over three-fold higher than that observed for the use of YE.

The maximal $\beta$-glucosidase produced by $A$. awamori, using YE, $\left(\mathrm{NH}_{4}\right)_{2} \mathrm{SO}_{4}, \mathrm{NaNO}_{3}$ or urea as nitrogen sources, as well as the cultivation time to reach the corresponding peak activities, are presented in Figure 1b. The response for $\beta$-glucosidase production was quite the opposite, as the medium containing yeast extract greatly favored the accumulation of this enzyme. As such, higher levels of $\beta$-glucosidase activity were obtained with the YE medium (10,470 $\pm 490 \mathrm{U} / \mathrm{L})$. The aforementioned average levels were 2 to 3 fold higher than that observed for the use of $\mathrm{NaNO}_{3}(4,460$ $\pm 110 \mathrm{U} / \mathrm{L}),\left(\mathrm{NH}_{4}\right)_{2} \mathrm{SO}_{4}(3,610 \pm 870 \mathrm{U} / \mathrm{L})$ or urea $(4,770 \pm$ $940 \mathrm{U} / \mathrm{L})$ as nitrogen source.

\section{Correlation of $\mathrm{pH}$ profiles of cultivations on media containing different nitrogen sources and xylanase, $\beta$-xylosidase, ferulic acid esterase and $\beta$-glucosidase production by $A$. awamori}

The $\mathrm{pH}$ profiles of the cultivations which were conducted in this study are presented in Figure 2. The metabolism of wheat bran, used as carbon source, jointly with 

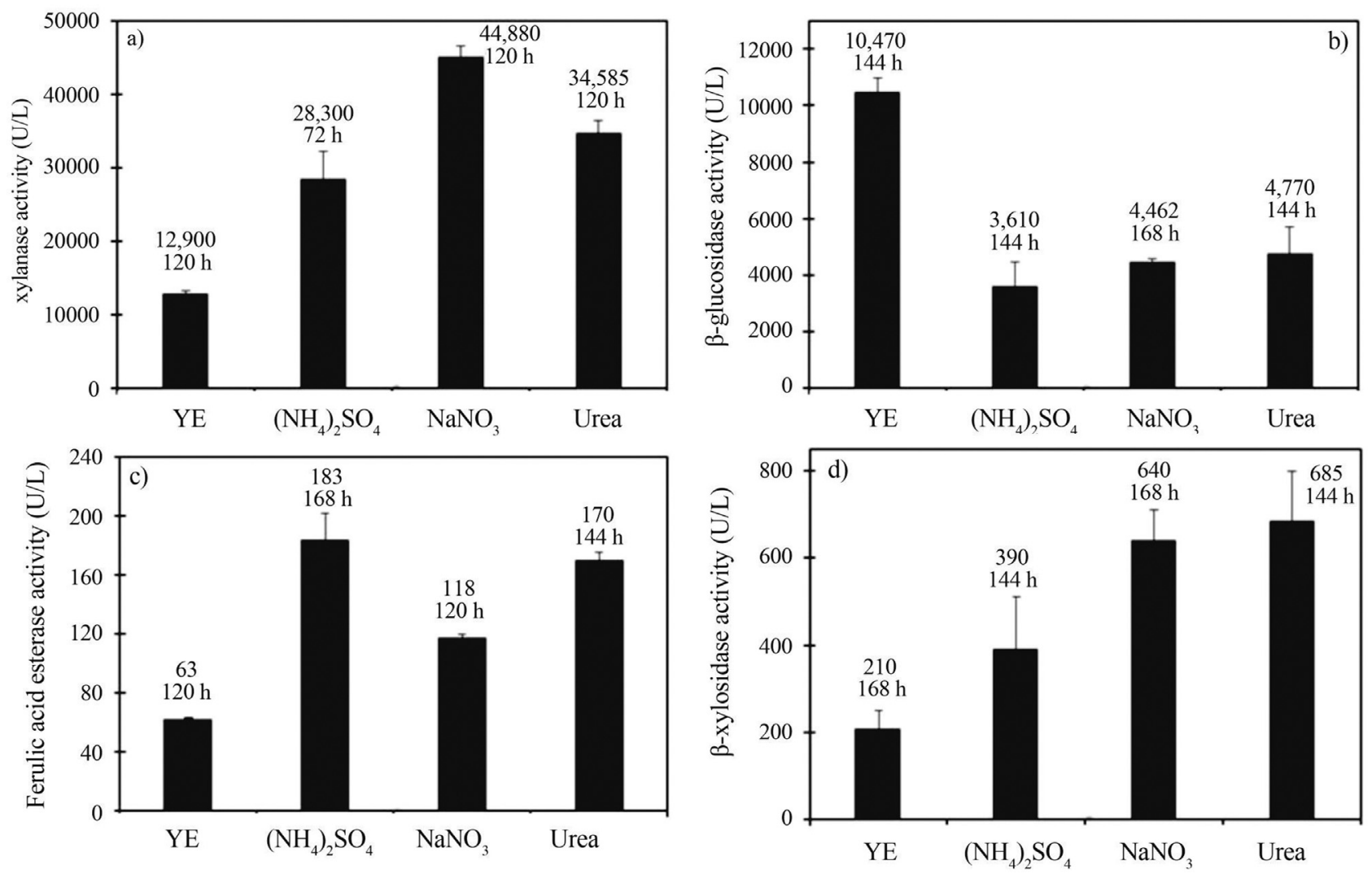

Figure 1 - Maximal accumulation of xylanase (a), $\beta$-glucosidase (b), ferulic acid esterase (c) and $\beta$-xylosidase (d) in the culture supernantants of Aspergillus awamori 2B.361 U2/1 comparing media with yeast extract (YE), sodium nitrate $\left(\mathrm{NaNO}_{3}\right)$, ammonium sulphate $\left(\left(\mathrm{NH}_{4}\right)_{2} \mathrm{SO}_{4}\right)$ or urea as nitrogen sources.

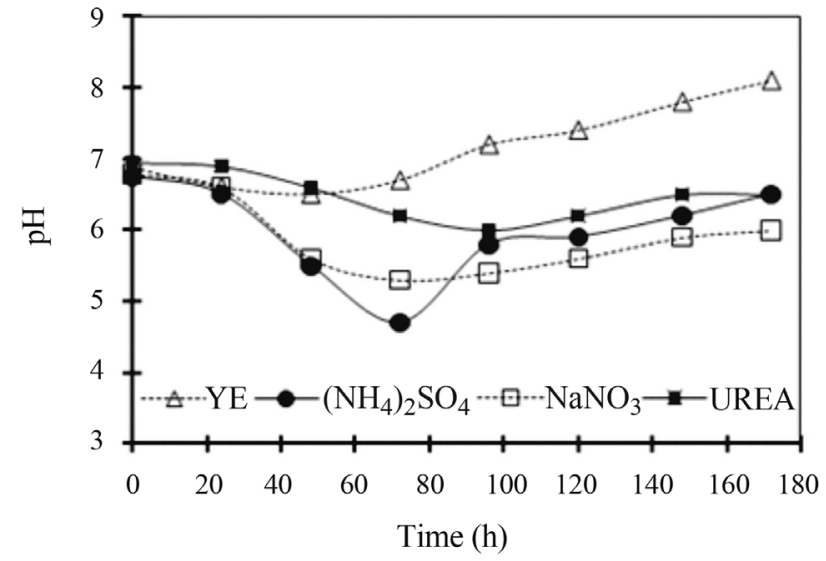

Figure 2 - pH profiles throughout the A. awamori fermentations using wheat bran as carbon source and yeast extract (YE), sodium nitrate $\left(\mathrm{NaNO}_{3}\right)$, ammonium sulphate $\left(\left(\mathrm{NH}_{4}\right)_{2} \mathrm{SO}_{4}\right)$ or urea (UREA) as nitrogen sources.

either $\mathrm{YE}, \mathrm{NaNO}_{3},\left(\mathrm{NH}_{4}\right)_{2} \mathrm{SO}_{4}$ and urea resulted on an initial $\mathrm{pH}$ decrease which was followed by $\mathrm{pH}$ increase whose range and time scale responded to each particular the nitrogen source. Minima and maxima $\mathrm{pH}$ values for the YE containing medium were in the range of 6.5 to 8.1 , whereas for nitrate and ammonium were of 5.3 to 6.8 and 4.7 to 6.8 , respectively. Urea showed the smallest $\mathrm{pH}$ range variation from 6.0 to 7.0. This is a quite interesting feature at industrial scale as the fermentation $\mathrm{pH}$ control could not be necessary. Peak enzyme activities for the YE, $\left(\mathrm{NH}_{4}\right)_{2} \mathrm{SO}_{4}$, $\mathrm{NaNO}_{3}$, and urea media were observed on the following $\mathrm{pH}$ ranges: 5.6 to 6.7 (xylanase), 6.0 to 7.8 ( $\beta$-xylosidase), 5.6 to 8.1 (ferulic acid esterase) and 5.9 to 8.1 ( $\beta$-glucosidase). Higher xylanase, $\beta$-xylosidase and ferulic acid esterase activity levels were observed in the $\mathrm{pH}$ range 5.5 to 6.5 which might indicate a higher stability of the enzyme protein under this $\mathrm{pH}$ range. As for $\beta$-glucosidase, the higher activity level was observed at $\mathrm{pH}$ values around 8.0, suggesting both enzyme release due to cell lyses and the enzyme protein high stability at this alkaline $\mathrm{pH}$ value.

Time course for the accumulation of xylanase, $\beta$-xylosidase, ferulic acid esterase and $\beta$-glucosidase in growth medium containing YE or urea as nitrogen source

According to data presented on Figure 3a the medium containing $30 \mathrm{~g} \mathrm{WB} / \mathrm{L}$ and $15 \mathrm{~g} \mathrm{YE} / \mathrm{L}$ significantly favored $\beta$-glucosidase accumulation $(10,470 \pm 490 \mathrm{U} / \mathrm{L})$, which was build up after the $3^{\text {rd }}$ fermentation day and concomitant to $\mathrm{pH}$ rise (Figure 2) suggesting enzyme release via cell lyses. $\beta$-xylosidase accumulation showed a similar pattern 

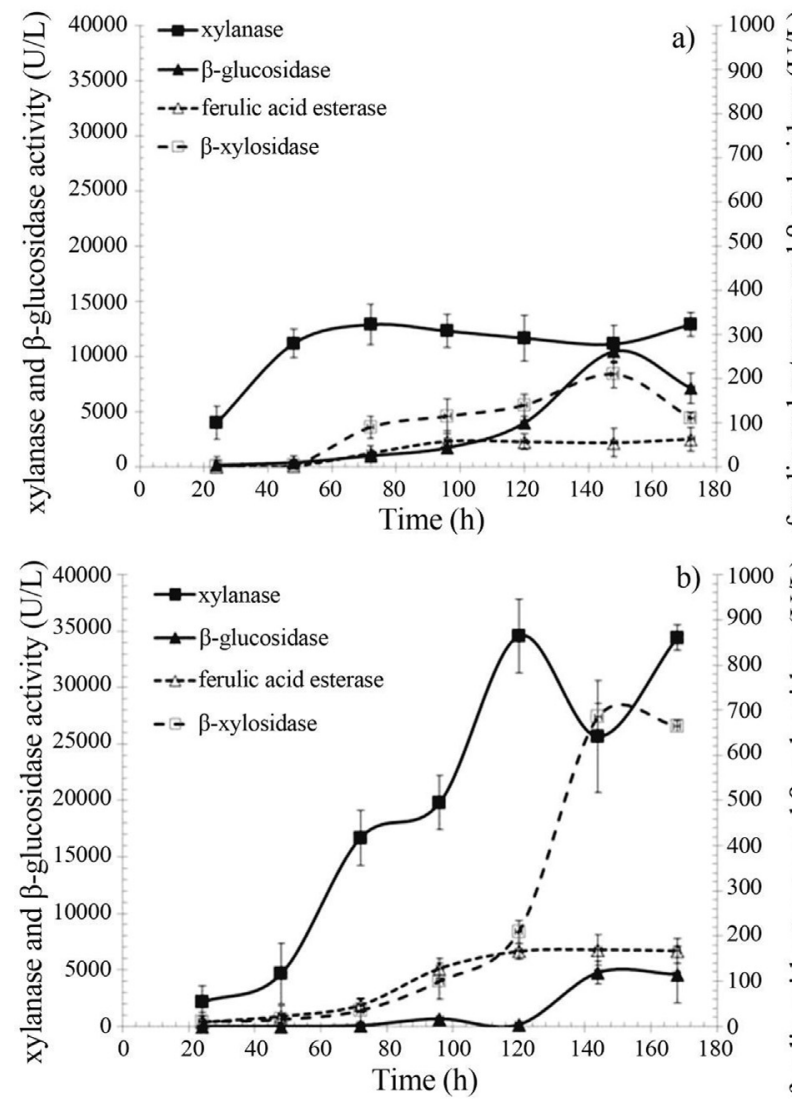

Figure 3 - Xylanase, $\beta$-glucosidase, ferulic acid esterase and $\beta$-xylosidase production profile of in the culture supernantants of Aspergillus awamori 2B.361 U2/1 using wheat bran as carbon source and (a) YE or (b) Urea as nitrogen source.

and peaked during the $\mathrm{pH}$ rise stage, reaching $210 \pm 20 \mathrm{U} / \mathrm{L}$. Xylanase and ferulic acid esterase accumulation, which showed to be growth associated, picked within $72 \mathrm{~h}$ of cultivation with maximal enzymes concentrations of $12,900 \pm$ 330 and $63 \pm 2 \mathrm{U} / \mathrm{L}$, respectively. All enzymes, except $\beta$-xylosidase, were quite stable under the cultivation conditions, which were carried out at $30{ }^{\circ} \mathrm{C}$ and presented a $\mathrm{pH}$ span from 6.2 to 8.1 .

The use of urea as nitrogen source (Figure $3 b$ ) favored significantly the build up of xylanase and ferulic acid esterase in the early cultivation stages, reaching $34,580 \pm$ 1,880 and $170 \pm 32 \mathrm{U} / \mathrm{L}$, respectively. The production of $\beta$-xylosidase was also greatly improved by the use of urea, a poor nitrogen source, such that it reached $685 \pm 110 \mathrm{U} / \mathrm{L}$, a value three-fold higher than that observed using the yeast extract. However, $\beta$-glucosidase accumulation of $4,770 \pm$ $940 \mathrm{U} / \mathrm{L}$ decreased two-fold.

\section{Comparison between A. awamori 2B.361 U2/1 and $T$. reesei Rut-C30 enzymes production profile}

The profile for cellulases and xylanases accumulation by $T$. reesei Rut-C30 and $A$. awamori $2 \mathrm{~B} .361 \mathrm{U} 2 / 1$ were compared to further the understanding on their en-
Table 2 - Maximal accumulations of FPase, CMCase, $\beta$-glucosidase, xylanase, $\beta$-xylosidase, ferulic acid esterase in the culture supernantants of A. awamori $2 \mathrm{~B} .361 \mathrm{U} 2 / 1$ and T. reesei RUT-C30 (means values \pm standard deviations).

\begin{tabular}{lcc} 
Enzyme activities & $\begin{array}{c}\text { Aspergillus awamori } \\
\text { 2B.361 U2/1 }\end{array}$ & $\begin{array}{c}\text { Trichoderma reesei } \\
\text { Rut-C30 }\end{array}$ \\
\cline { 2 - 3 } & \multicolumn{2}{c}{ Supernatant concentration (U/L) } \\
\hline Filter paper activity & $190 \pm 10^{\mathrm{a}}$ & $1,200 \pm 140$ \\
Carboxymethyl cellulase & $2,500 \pm 140^{\mathrm{a}}$ & $25,000 \pm 1,970$ \\
$\beta$-glucosidase & $10,470 \pm 490^{\mathrm{a}}$ & $600 \pm 50$ \\
Xylanase & $34,580 \pm 1,880^{\mathrm{b}}$ & $15,000 \pm 700$ \\
$\beta$-xylosidase & $685 \pm 110^{\mathrm{b}}$ & $290 \pm 25$ \\
Ferulic acid esterase & $170 \pm 32^{\mathrm{b}}$ & 0
\end{tabular}

${ }^{a}$ Activities levels obtained using medium containing YE as nitrogen sources.

${ }^{\mathrm{b}}$ Activities levels obtained using medium containing urea as nitrogen source.

zyme pools characteristics and activities balance towards biomass hydrolysis (Table 2). The culture media used for T. reesei Rut-C30 enzyme production was chosen in accordance with the most commonly described conditions for cellulases production by this microorganism. Thus, by comparing the $A$. awamori $2 \mathrm{~B} .361 \mathrm{U} 2 / 1$ and $T$. reesei Rut-C30 enzymes production profile it is possible to assess the adequacy of A. awamori crude extract to supplement $T$. reesei Rut-C30 enzymes in order to obtain an effective blend for biomass hydrolysis. It was found that A. awamori $2 \mathrm{~B} .361 \mathrm{U} 2 / 1$, grown in YE produced outstanding $\beta$-glucosidase levels $(10,470 \pm 490 \mathrm{U} / \mathrm{L})$ as compared to $T$. reesei Rut-C30 (600 $\pm 50 \mathrm{U} / \mathrm{L})$. However, the levels of CMCase $(2,500 \pm 140 \mathrm{U} / \mathrm{L})$ and FPase $(190 \pm$ $10 \mathrm{U} / \mathrm{L}$ ), in this medium were approximately 5 - to 10 - fold lower than those observed for T. reesei Rut-C30 (25,000 \pm $1,970 \mathrm{U} / \mathrm{L}$ of CMCase activity and 1,200 $\pm 140 \mathrm{U} / \mathrm{L}$ of FPase activity).

Xylanase and $\beta$-xylosidase accumulation was also high in the urea medium, reaching $34,590 \pm 3,250$ and 685 $\pm 110 \mathrm{U} / \mathrm{L}$, respectively, that compares well to those produced by the T. reesei Rut-C30, of 15,000 \pm 700 and $290 \pm$ $25 \mathrm{U} / \mathrm{L}$, respectively. Moreover, A. awamori produced high levels of ferulic acid esterase ( $170 \pm 32 \mathrm{U} / \mathrm{L})$, an enzymatic activity that was not detected in the $T$. reesei supernatant. The use of a concentrate enzymatic blend which was obtained with the supernatants of $A$. awamori 2B.361 U2/1 and $T$. reesei Rut- $\mathrm{C} 30$ and presenting the following activity profile $(2,000 \mathrm{U} / \mathrm{L}$ of FPase, 24,000 U/L of CMCase, $23,000 \mathrm{U} / \mathrm{L}$ of $\beta$-glucosidase, $52,000 \mathrm{U} / \mathrm{L}$ of xylanase) has been already used to efficiently hydrolyze sugarcane bagasse (Gottschalk et al., 2010). 


\section{Discussion}

In this work, the production of xylanase, $\beta$-xylosidase, ferulic acid esterase and $\beta$-glucosidase by Aspergillus awamori 2B.361 U2/1 was evaluated using selected conditions regarding nitrogen nutrition. Nitrogen nutrition is an important factor when industrial fermentation process are taken into account as it has a high impact on costs and it may also selectively affect both, cell growth and product formation in response to the basic biochemical steps related to their use by the cell. As far as amino acids are concerned, they are assimilated and directly incorporated into proteins, and are not first degraded into ammonia. This process favors biomass accumulation, and the available carbon source is highly allocated into it. Abundant nitrogen is incorporated into cell constituents with a consequent increase in the rate of respiration and the carbon source consumption. With respect to ammonium, nitrate and urea, their use is limited by the rate at which these components are incorporated into their organic counterparts. Furthermore, nitrate and urea goes, beforehand, through specific metabolic pathways which convert its nitrogen content into the readily metabolized ammonia (Bon and Webb, 1993). In this work, media containing inorganic nitrogen or urea favored enzymes accumulation in comparison to that containing the more expensive yeast extract. The advantages of urea for enzymes production are well orchestrated with the need to decrease the cost of fermentations for industrial enzymes production. Indeed, while the cost of YE can reach US\$ 1,900 per ton, the cost of urea of US\$ 360-380 per ton, is five-fold lower (Nascimento et al., 2010).

Concerning the carbon source, preliminary experiments carried out in our laboratory showed that wheat bran was an adequate carbon source for $A$. awamori cultivation. Wheat bran is composed predominantly of non-starch carbohydrates, starch and crude protein. The non-starch carbohydrates are primarily arabinoxylans, cellulose and $\beta$ (1-3)(1-4)-glucan, which may induce xylanase production (Haltrich et al., 1996; Sun et al., 2008). Indeed, high levels of xylanase were obtained in this work when wheat bran was used as carbon source. It was also reported that $A$. awamori produces high levels of ferulic acid esterase when cultivated on wheat bran medium (Kaunachi et al., 2008).

In uncontrolled $\mathrm{pH}$ fermentations, variations in the early stages are mostly related to the microorganism physiological response towards substrates uptake, whereas in the later stages cell lyses may play a bigger role. Lyses are followed by proteolysis and aminoacids deamination with their conversion into the corresponding keto acid by the removal of the amine functional group as ammonia. This augment on ammonia concentration in the growth media leads to $\mathrm{pH}$ increase. Thus, the enzyme activity peaks presented in here might reflect a balance between the excretion of the enzyme and its external inactivation by a denaturating $\mathrm{pH}$ environment. Regarding xylanase activity, it was reported that the crude xylanase from $A$. carneus M34 was stable in the range of 3-10 ( $>70 \%$ relative activity) for $24 \mathrm{~h}$ at room temperature. It is also reported that $A$. japonicus xylanase retained more than $80 \%$ of its original activity over a wide $\mathrm{pH}$ range, from 2.0 to 9.0 (Wakiyama et al., 2010). These results substantiate the finding that most crude xylanases of fungal origin are stable over a broad $\mathrm{pH}$ range. Concerning the $\beta$-xylosidase and ferulic acid esterase, $A$. japonicus $\beta$-xylosidase had retained more than $90 \%$ of its original activity between $\mathrm{pH} 2.0$ and 7.0 at room temperature for 3 hours (Wakiyama et al., 2008) and the $A$. awamori ferulic acid esterase showed to be stable within the $\mathrm{pH}$ range 4.5 to 6.5 (Fazary et al., 2009). The $\mathrm{pH}$ studies for fungal $\beta$-glucosidase showed the enzyme to be stable up to $60 \mathrm{~min}$ at $50^{\circ} \mathrm{C}$ over a $\mathrm{pH}$ range of 4.0-8.0 (Peralta $e t$ al., $1997)$ and a maximum activity in an acidic $\mathrm{pH}$ range 4.0-6.0 (Joo et al., 2010; Teixeira et al., 2010). The $A$. awamori $\beta$-glucosidase produced in this work showed to be quite stable in a $\mathrm{pH}$ value as high as 8.1 , in accordance to the literature.

Additionally, enzyme levels of A. awamori were compared to that of $T$. reese $i$ Rut-C30 aiming to find out complementary activities and activity levels to design a complete blend for biomass enzymatic hydrolysis. $A$. awamori produces $\beta$-glucosidase in high yields which is of importance for the supplementation of the $T$. reesei cellulases pool. However, the highest $\beta$-glucosidase accumulation was observed when yeast extract was used, which is a rich organic nitrogen source that favors fungal biomass accumulation but very costly for industrial processes.

In conclusion, $A$. awamori $2 \mathrm{~B} .361 \mathrm{U} 2 / 1$ showed to be an outstanding fungal strain for the production of xylan hydrolyzing enzymatic pool. It was shown that $A$. awamori performed well when urea was used as a nitrogen source, which comparatively presents cost advantage and keeps the cultivation $\mathrm{pH}$ within a desirable fluctuation range. Under these conditions, this work presented a feasible process for the production of xylanase, ferulic acid esterase and $\beta$-xylosidase, which are of outmost importance for the supplementation of cellulases preparations aiming for the biomass saccharification.

\section{Acknowledgments}

This work was supported by the Research and Projects Financing (FINEP), The Brazilian Research Council (CNPq) and by the Brazilian Federal Agency for Support and Evaluation of Graduate Education (CAPES). The authors are thankful to Dr. Marília Martins Nishikawa from Oswaldo Cruz Foundation (FIOCRUZ) for the fungi strains preservation and validation and to Bárbara Barcelos da Silva for technical support. 


\section{References}

Ahmed I, Zia MA, Iftikhar T, Iqbal HMN (2011) Characterization and detergente compatibility of purified protease produced from Aspergillus niger by utilizing agro wastes. Bioresources 6:4505-4522.

Anindyawati T, Ann Y, Ito K, Iizuka M, Minamiura N (1998) Two kinds of novel $\alpha$-glucosidases from Aspergillus awamori KT-11: Their purifications, properties and specificities. J Ferment Bioeng 85:465-469.

Bastawde KB (1992) Xylan structure, microbial xylanases, and their mode of action. World J Microbiol Biotechnol 8:353368.

Bon EPS, Webb C (1989) Passive Immobilization of Aspergillus awamori Spores for Subsequent Glucoamylase Production. Enzyme Microb Technol 11:495-499.

Bon EPS, Webb C (1993) Glucoamylase production and nitrogen nutrition in Aspergillus awamori. Appl Biochem Biotechnol 39:349-369.

Bon EPS, Gottschalk LMF, Ferrara MA, Eleutherio ECA, Ferreira EX, Moreira LRS, Pereira MD, Silva AS, Teixeira RSS, Webb C (2009) Composition to hydrolyze lignocellulosic material comprises enzymes and beta-glucosidase, obtained by fermentation with Trichoderma reesei and enzymes, beta-glucosidase and accessory enzymes obtained by fermentation with Aspergillus awamori. Patent Number WO2009065199-A1, Brazil.

Botella C, Diaz A, Ory I, Webb C, Blandino A (2007) Xylanase and pectinase production by Aspergillus awamori on grape pomace in solid state fermentation. Process Biochem 42:98-101.

Duff SJB, Cooper DG, Fuller OM (1987) Effect of medium composition and growth conditions on production of cellulase and b-glucosidase by a mixed fungi fermentation. Enzyme Microb Technol 9:47-52.

Duenas R, Tengerdy RP, Gutierrez-Correa M (1995) Cellulase production by mixed fungi in solid-substrate fermentation of bagasse. World J Microbiol Biotechnol 11:333-337.

Fazary AE, Ismadji S, Ju YH (2009) Stability and solubility studies of native and activated Aspergillus awamori feruloyl esterase. J Mol Catal B Enzym 59:190-196.

Ferreira-Leitão V, Gottschalk LMF, Ferrara MA, Nepomuceno AL, Molinari HBC, Bon EPS (2010) Biomass residues in Brazil: Availability and potential uses. Waste Biomass Valor 1:65-76.

Ghose TK (1987) Measurement of cellulase activities. Pure Appl Chem 59:257-268.

Gosh BK, Gosh A (1992) Degradation of cellulose by fungal cellullase. In: Winkelmann G (ed) Microbial Degradation of Natural Products. VCH Publishers Inc., New York, pp 84126.

Gottschalk LMF, Oliveira RA, Bon EPS (2010) Cellulases, xylanases, $\beta$-glucosidase and ferulic acid esterase produced by Trichoderma and Aspergillus act synergistically in the hydrolysis of sugarcane bagasse. Biochem Eng J 51:72-78.

Gutierrez-Correa M, Tengerdy RP (1997) Production of cellulose on sugar cane bagasse by fungal mixed culture solid substrate fermentation. Biotechnol Lett 19:665-670.

Haltrich D, Nidetzky B, Kulbe KD, Steiner W, Zupancic S (1996) Prodution of fungal xylanases. Biores Technol 58:137-161.
Howell JA, Stuck JD (1975) Kinetics of solka floc cellulose hydrolysis by Trichoderma viride cellulose. Biotechnol Bioeng 17:873-893.

Jones DB, Gersdorff CEF (1925) Proteins of wheat bran: II. Distribution of nitrogen, percentages of amino acids and of free amino nitrogen: a comparison of the bran proteins with the corresponding proteins of wheat endosperm and embryo. J Biol Chem 64:241-251.

Joo A, Jeya M, Lee K, Lee K, Moon H, Kim Y, Lee J (2010) Production and characterization of $\beta$-1,4-glucosidase from a strain of Penicillium pinophilum. Process Biochem 45:851858.

Kaunachi M, Watanabe S, Tsukada T, Atta K, Kakuta T, Koizumi $\mathrm{T}$ (2008) Purification and characteristics of feruloyl esterase from Aspergillus awamori G-2 strain. J Food Sci 73:458463.

Koseki T, Furuse S, Iwano K, Sakai H, Matsuzawa H (1997) An Aspergillus awamori acetylesterase: purification of the enzyme, and cloning and sequencing of the gene. Biochem J 326:485-490.

Koseki T, Takahashi K, Handa T, Yamane Y, Fushinobu S, Hashizume K (2006) N-linked oligosaccharides of Aspergillus awamori feruloyl esterase are important for thermostability and catalysis. Biosci Biotechnol Biochem 70:2476-2480.

Kurakake M, Komaki T (2001) Production of beta-mannanase and beta-mannosidase from Aspergillus awamori K4 and their properties. Curr Microbiol 42:377-380.

Kurakake M, Fijii T, Yata M, Okazaki T, Komaki T (2005) Characteristics of transxylosylation by $\beta$-xylosidase from Aspergillus awamori K4. Biochimica Biophysica Acta 1726:272-279.

Lemos JLS, Bon EPS, Santana MD, Pereira N (2000) Thermal stability of xylanases produced by Aspergillus awamori. Braz J Microbiol 31:206-211.

Mandels M, Weber J (1969) Production of cellulases. Adv Chem Ser 95:391-414.

Nandini CD, Salimath P V (2001) Carbohydrate composition of wheat bran, sorghum and bajra with good chapatti/roti (Indian flat bread) making quality. Food Chem 73:197-203.

Nascimento RP, Junior NA, Pereira N, Bon EPS, Coelho RRR (2010) Brewer's spent grain and corn steep liquor as substrates for cellulolytic enzymes production by Streptomyces malaysiensis. Lett Appl Microbiol 48:529-535.

Neustroev KN, Krylov AS, Firsov LM, Abroskina OL, Khorlin AY (1991) Isolation and propertics of $\beta$-mannosidase from Aspergillus awamori. Biokhimiya 56:1406-1412.

Pavezzi FC, Gomes E, da Silva R (2008) Production and characterization of glucoamylase from fungus Aspergillus awamori expressed in yeast Saccharomyces cerevisiae using different carbon source. Braz J Microbiol 39:108-114.

Peralta RM, Kadowaki MK, Terenzi HF, Jorge JA (1997) A highly thermostable $\beta$-glucosidase activity from the thermophilic fungus Humicola grisea var. thermoidea: purification and biochemical characterization. FEMS Microbiol Lett 146:291-295.

Rosenberg SL (1980) Fermentation of pentose sugars to ethanol and other neutral products by microorganism. Enzyme Microb Technol 2:185-193.

Stockton BC, Mitchell DJ, Grohmann K, Himmel ME (1991) $\beta$-D-glucosidase supplementation of cellulose for efficient 
conversion of cellulose to glucose. Biotechnol Lett 13:5762 .

Sun X, Liu Z, Qu Y, Li X (2008) The effects of wheat bran composition on the production of biomass-hydrolyzing enzymes by Penicillium decumbens. Appl Biochem Biotechnol 146:119-128.

Teixeira RSS, Silva AS, Ferreira-Leitão VS, Bon EPS (2012). Amino acids interference on the quantification of reducing sugars by the 3,5-dinitrosalicylic acid assay mislead carbohydrase activity measurements. Carbohydr Res 363: 33-37.

Teixeira RSS, Siqueira FG, Souza MV, Ferreira-Filho EX, Bon EPS (2010) Purification and characterization studies of a thermostable $\beta$-xylanase from Aspergillus awamori. J Industrial Microbiol Biotechnol 37:1041-1051.

Umsza-Guez MA, Díaz AB, Ory I, Blandino A, Gomes E, Caro I (2011) Xylanase production by Aspergillus awamori under solid state fermentation conditions on tomato pomace. Braz J Microbiol 42:1585-1597.
Wakiyama M, Yoshihara K, Hayashi S, Ohta K (2008) Purification and properties of an extracellular $\beta$-xylosidase from Aspergillus japonicus and sequence analysis of the encoding gene. J Biosci Bioeng 106:398-404.

Wakiyama M, Yoshihara K, Hayashi S, Ohta K (2010) An extracellular endo-1,4- $\beta$-xylanase from Aspergillus japonicus: Purification, properties, and characterization of the encoding gene. J Biosci Bioeng 109:227-229.

Wen Z, Liao W, Chen S (2005) Production of cellulase/ $\beta$-glucosidase by the mixed fungi culture Trichoderma reesei and Aspergillus phoenicis on dairy manure. Process Biochem 40:3087-3094.

Zhang C, Zhong Y, Sun X, Ma Y (2009) Purification and characterization of SDG- $\beta$-d-glucosidase hydrolyzing secoisolariciresinol diglucoside to secoisolariciresinol from Aspergillus oryzae. Process Biochem 44:607-611.

All the content of the journal, except where otherwise noted, is licensed under a Creative Commons License CC BY-NC. 